\title{
B208 マッハツェンダー干渉計による超臨界二酸化炭素流れの温度分布計測
}

\author{
桜井克巳 ○、高漢瑞、岡本 孝司、班目 春樹 (東大) \\ Measurement of temperature distribution of supercritical fluids \\ using Mach-Zehnder interferometer
}

\author{
Katsumi SAKURAI*, KO Han Seo*, Koji OKAMOTO*, Haruki MADARAME*
}

For development of nuclear reacter or other boilers that use supercritical water, importance of experimental knowledge is increasing to investigate thermal characteristic of supercritical fluid, which is very peculiar. It is well known that there occurs heat transfer enhancement and deterioration in supercritical fluid, however, it is very hard to observe in a case of forced convection because of difficulties in high pressure and temperature. In this study, boiling-like phenomenon in forced convection heat transfer was observed by white-light illumination. Also dependency of boiling to physical parameters was examined. Moreover, Mach-Zehnder interferometer was also applied to investigate temperature distribution in the flow. Temperature variation around the heated wall was measured by interferogram.

Keywords: supercritical pressure, carbon dioxide, forced convection heat transfer, Mach-Zehnder interferometer

\section{1. 序論}

超臨界圧ボイラの実用化や超臨界圧水を冷却材に用 いた新型炉の開発などに伴い、超臨界流体の熱伝達特 性の解明は大きな課題となって進められている(1)。一 般に超臨界域において流体は密度、比熱などの物性值 が気相、液相の通常状態に比べて温度に依存して連続 的に大きく変動するため、それらを制御パラメー夕に して工学、化学的に様々な応用がなされている。熱工 学的には、熱伝達率の増大などが注目されている(2)(3) 。とりわけ臨界近傍で定圧比熱は急激な変化を起こし、 疑似臨界点と呼ばれる臨界点より数度高い温度でピー クを持つ。この領域では、低い熱流束に対しては大幅 な伝熱促進が起こるが、質量速度が充分高い条件では、 熱流束が高くなるにつれ、伝熱劣化が生じてくる。こ のような特殊な性質は数多く報告され、議論されてき た。また、気液の区別が無い超臨界状態においても沸

* Nuclear Engineering Research Laboratory, University of Tokyo, Tokai-mura, Ibaraki, 319-11
騰に近い現象が発生することは知られている。この現 象が伝熱に寄与している部分があるとも考えられてい る。こういった現象をを含め、超臨界流体の強制対流 の熱伝達における流れの様子は工学上重要な問題では あったが、可視化画像で観測することは、超臨界流体が 高温高圧で取扱いが困難なこともあって、少なかった。

本研究では、超臨界流体の加熱流動に耐用する高圧 容器流体を用い、矩形流路を垂直上昇させながら壁面 から加熱する強制対流熱伝達の条件で疑似沸騰を発生 させ、それを白色光とレーザーを用いたマッハツェン ダー干渉計で可視化計測実験を行った。

\section{2. 実験装置}

ループ装置の概要は以下のようになっている。二酸 化炭素はボンベから約 $6 \mathrm{MPa}$ の圧力で供給され、冷却 タンク内で 10 度ほどで水冷されてから液化された状 態でメインタンクに貯蔵される。さらに数度以下まで 冷却され、ポンプで加圧される。ポンプはダイアフラ ム型を用い、吸い达み圧力はタンク圧力と同じ $6 \mathrm{MPa}$ で、流量は最大で $155 \mathrm{~L} / \mathrm{H}$ である。ポンプは一定流量 


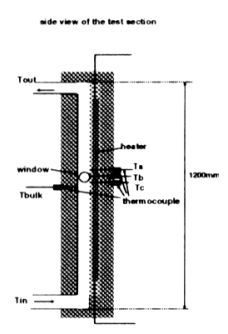

Fig.1 sideview of the testsection

で作動し、圧力コントロールはフィードバック電子制 御式のコントロールバルブで行い、設定值に一定に保 たれる。また、熱媒漕を通過させることで流体はテス トセクション手前で一定のバルク温度に調節される。

図 1 は可視化測定用のテストセクションである。垂直 上昇の矩形流路で、長さは $600 \mathrm{~mm}$ 、流路面積は $10 \mathrm{~cm}$ x $20 \mathrm{~cm}$ である。流路の片面全体が銅ブロックで、容 量 $600 \mathrm{~W}$ のヒーター壁になっている。熱電対は流体入 口温度、出口温度、テストセクション中間での流体温 度と、ヒーターに 6 䇢所設置した。可視化測定用空は 流路途中に設けられている。空には高温高圧耐用のガ ラスでなおかつ可視化波長で光を減衰させない特殊な ものを使用した。直径は $23 \mathrm{~mm}$ で、肉厚は $60 \mathrm{~mm}$ で ある。

この装置において、強制対流熱伝達、疑似沸騰を観 測するために、白色光源による可視化とマッハツェン ダー干渉計による温度分布計測を行った。白色光源に よる可視化は、疑似沸騰発生時の密度变動により光が 散乱され、透過光が減衰するのを観察するためである。

また、壁面近傍の温度分布を可視化するために $15 \mathrm{~mW} 、 532 \mathrm{~nm}$ の He-Neレーザーを用いたマッハッェ ンダー干渉計を適用した。

\section{3. 実験結果}

酸化炭素の臨界点は压力：7.38 MPa、温度：31.1 ${ }^{\circ} \mathrm{C}$ である。白色光による実験条件は流体バルク温度を $31^{\circ} \mathrm{C}$ 、圧力を $7.4 \mathrm{MPa}$ 、ヒーター出力は $576 \mathrm{~W}$ とした。 臨界近傍に設定し、テストセクション内で疑似臨界に 達する条件にした。図 2 は得られた画像である。円形 の可視化空内の右側の黒い部分は壁面である。疑似沸 騰は、暗い領域となって見えている。また、ほかのパ ラメータの条件を同じにして圧力を $9.0 \mathrm{MPa}$ に上昇し て行った実験では、疑似沸騰は発生しなかった。これ は圧力上昇に伴って疑似臨界点が上昇したためである と思われる。

次に、マッハツェンダー干渉計によって得られた温 度分布画像を示す。これは圧力 $9.0 \mathrm{MPa}$ 、流体バルク 温度 $31^{\circ}$ である。ヒーター出力は $100 \mathrm{~W}$ ほどで低くし

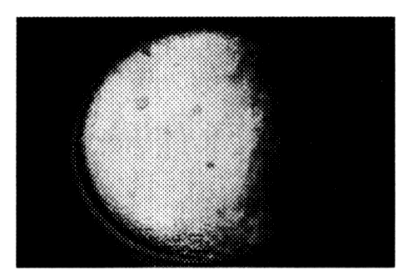

Fig. 2 image of boiling-like phenomena

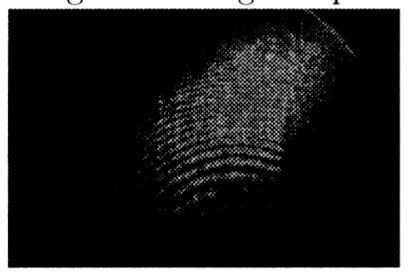

Fig. 3 initial condition of interferogram

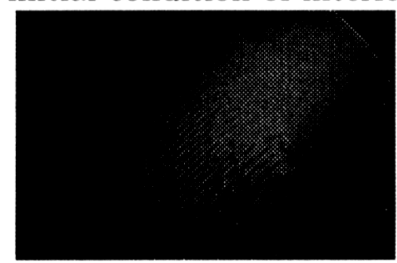

Fig. 4 temperature distribution by interferometer

てある。これは、疑似沸騰が発生する条件だと密度変 動が激しすきてて渉縞が消滅するからである。図 4 は 初期状態の、ヒーターを用いていない状態の干渉縞で ある。干渉縞は、ここでは温度上昇に伴って上側にシ フトするセッティングにしてある。ヒーター壁面から 入熱のある状態は図 5 である。やや縞は乱れているが、 壁面近傍で縞が上側にシフトしているのがわかる。

\section{4. 結論}

超臨界圧二酸化炭素について、強制対流熱伝達の内 部の状態を可視化することに成功した。また、それに 伴う疑似沸騰現象も可視化し、マッハッェンダー干涉 計を用いて温度分布の变動の可視化も行った。強制対 流状態でも、壁面付近で通常のものと同じような疑似 沸騰が観測され、压力条件などによる発生の違いも示 された。

\section{参考文献}

[1]Y.Oka, S.Koshizuka and T.Yamasaki J.Nucl.Sci.Technol.29,585-588(1992)

[2]N.L.Dickinson and C.P.Welch, Trans.Am.Soc.Mech.Engrs, 80,746(1958) [3]S.Koshizuka, N.Takano and Y.Oka, Int.J.Heat Mass Transfer,

Vol.38,No.16,pp3077-3084(1995) 